\title{
Racionalidade e Retórica em Aristóteles
}

\author{
Rationality and Rhetoric in Aristotle
}

\author{
Tiago Penna \\ (Universidade Federal de Alagoas, Brasil)
}

\section{Resumo}

Ao admitirmos que aquilo a que cunhamos racionalidade se identifica com os gêneros de discursividade (lógos), tal racionalidade pode ser re-conhecida através de análise formal dos elementos constitutivos próprios a cada esfera de racionalidade discursiva (lógos). No caso da arte retórica (rethorikê), a matéria do discurso, isto é, as palavras (lógoi), são ordenadas em vista da produção (poiésis) de um "efeito" (érgon), que se identifica com a persuasão (peithós), estritamente ligada a contextos particulares ou casos concretos. Neste sentido, é crucial a compreensão e a prática das "provas" (písteis), de acordo com uma forma (êidos) adequada, que consistirá no (i) raciocínio (lógos) inerente ao discurso; bem como deverá exprimir o (ii) "caráter" (éthos) ou "boa reputação" do orador - considerado como causa motora (ou eficiente) do discurso retórico; e (3) o páthos, isto é, as paixões ou emoções suscitadas através do discurso. Assim, as "provas de persuasão" (písteis) podem ser classificadas como provas lógicas, éticas ou emocionais (patéticas). Aristóteles distingue entre provas artísticas, isto é, intrínsecas (ou técnicas), e as não-artísticas, extrínsecas (ou não-técnicas), isto é, obtidas de modo alheio à arte retórica (rethorikê); enquanto as provas "artísticas" ou técnicas dizem respeito àquelas provas obtidas por meio das regras ou "caminhos" (méthodoi) próprios da retórica (rethorikê), compreendida como arte (techné) de produção (poiésis) de discursos (lógoi) que visam à persuasão (peithós). Portanto, a retórica (rethorikê) aponta para um gênero específico de arte, que - por sua vez - incide em um gênero específico de racionalidade discursiva (lógos), de modo que a mesma se apresenta como espécie de "saber" (epistême). Assim, resta-nos analisar se tal racionalidade inerente a esta espécie de discursividade (lógos) se assemelha com o método (méthodos) próprio da retórica, reconhecida como espécie de conhecimento (epistême).

Palavras-chave: Aristóteles. Retórica. Discursividade. Arte. Persuasão.

\begin{abstract}
When we admit that what we call rationality identifies with the genres of discursivity (lógos), such rationality can be re-known through formal analysis of the constitutive elements proper to each sphere of discursive rationality (lógos). In the case of rhetorical art (rethorikê), the matter of discourse, that is, words (lógoi), are ordered in view of the production (poiésis) of an "effect" (érgon), which is identified with persuasion (peithós), strictly linked to particular contexts or concrete cases. In this sense, the understanding and practice of "proofs" (pisteis) according to an adequate form (êidos), which consists of (i) the reasoning (lógos) inherent in the discourse is crucial; (ii) "character" (éthos) or "good reputation" of the orator - considered as motor (or efficient) cause of rhetorical discourse; and (3) the páthos, that is, the passions or emotions aroused through discourse. Thus, "persuasion tests" (písteis) can be classified as logical, ethical or emotional (pathetic) evidence. Aristotle distinguishes between artistic proofs, that is, intrinsic (or technical) proofs, and non-artistic, extrinsic (or non-technical) proofs, that is, obtained in a way unrelated to rhetorical art (rethorikê); while the "artistic" or technical proofs refer to those proofs obtained through rules or "ways" (méthodoi) proper to rhetoric (rethorikê), understood as art (techné) of production (poiésis) of discourses (lógoi) that aim at persuasion (peithós). Therefore, rhetoric (rethorikê) points to a specific genre of art, which - in turn - focuses on a specific genre of discursive rationality (lógos), so that it presents itself as a kind of "knowing" (epistême). Thus, it remains to analyze whether such rationality inherent in this kind of discursivity (lógos) is similar to the method (méthodos) proper of rhetoric, re-known as a kind of knowledge (epistême).
\end{abstract}

Key words: Aristotle. Rhetoric. Discursiveness. Art. Persuasion. 


\section{Introdução: Da racionalidade da arte}

Nosso intento, no presente artigo, é suscitar o debate acerca da racionalidade subjacente à arte, em geral, e à arte retórica, em particular, no pensamento de Aristóteles. Nossa metodologia incindirá na exposição acerca de certos aspectos do pensamento aristotélico acerca da arte, em geral, e da retórica, em particular - por meio da análise de conceitos relacionados em seu corpus teórico. Para tanto, tomaremos alguns trechos específicos de suas obras, admitidos como relevantes para a elaboração do presente trabalho, tendo em vista o intuito de desvelar o que chamaremos de racionalidade retórica, com vistas a distingui-la de outros gêneros específicos de racionalidade (ou de proceder, através de métodos distintos, admitidos pelo filósofo estagirita), e investigar se os gêneros de racionalidade (dianóia) se identificam de algum modo com formas de discursividade (lógos), e portanto, de saber (epistême), em Aristóteles.

Inicialmente, deveremos distinguir alguns termos gregos, e algumas de suas diversas acepções, especialmente perante o corpus aristotélico. Para tanto, introduziremos algumas noções sobre o conceito de arte, debruçando-nos especialmente sobre os termos teckné e poiésis, que de maneira geral são admitidos como sinônimos de arte; para tanto, deveremos distinguir, também, a arte (techné) da experiência (empeiría) e da ciência (epistême), sempre de acordo com o pensamento aristotélico. Em seguida, iniciaremos nossa análise por sugerir algumas propostas acerca daquilo que podemos chamar de racionalidade, a partir de interpretações de alguns estudiosos do tema, no pensamento aristotélico. Por fim, tendo em vista as diferentes formas de racionalidade admitidas por Aristóteles - a partir do que 
chamaremos de tolerância epistêmica -, analisaremos o modo de proceder da retórica, e suas particularidades específicas, próprias de seu gênero específico de argumentação (lógos), quando, por fim, também a retórica, no pensamento de Aristóteles, pode ser considerada como uma forma autêntica de racionalidade, e se tal acepção seria admissível como forma de saber específico (epistême), ou ao menos de nos relacionarmos de algum modo com a "verdade" (alethéia).

\section{Arte e Racionalidade}

O termo teckné, entendido como sinônimo de "arte", também poderia ser traduzido como técnica, ou uma espécie de habilidade (manual ou intelectual) inerente À disposição da alma (dýnamis) que visa à produção (poiésis) de um artefato ou produto diferente do agente inteligente (o artífice) que produz tal objeto de arte; portanto, a techné pode ser entendida como construção, e-laboração por meio da confecção, "criação" ou com-posição de uma síntese estética que represente ou mimetize de algum modo a realidade, e que, por fim, exerça uma "função" ou "efeito" (érgon), e seja passível de formalização de uma espécie de conhecimento prático, através de um "caminho" (méthodos).

A techné, portanto, é encarada como uma produção humana que a distingue dos seres naturais, cuja causa de sua geração está contida neles mesmos, e que por outro lado, a mimetiza de algum modo. Por seu turno, o termo poiésis significa o ato de produção, ou fabricação, inerente ao fazer - e que a distingue do agir inerente à ação prática (práxis).

Em Aristóteles, a dýnamis poietikê é a força criadora da ação inteligente que dá forma a uma matéria (que a 
organiza, ordena), e instaura um novo ser, isto é, o artefato, ou o que chamaremos de "obra" ou objeto de arte. A poiésis aponta para uma abrangência mais abstrata acerca do ato inteligente que compõe uma coisa (obra ou produto), diferente do ser inteligente que a produz. Neste sentido, o agente criador é o "poeta", o artista que cria ou inventa "poesias" (fruto da atividade criadora), que de maneira particular são chamados de "poemas" (obras de belas-artes) ${ }^{1}$.

De fato, há um lógos específico que acompanha a arte enquanto capacidade de fazer ou produzir², relacionado, portanto, a uma habilidade específica que reside no artífice, e se identifica com a "posse da arte", que, por sua vez, está relacionada pois a um método que expressa a racionalidade inerente à atividade produtiva da arte. Neste sentido, o lógos verdadeiro se identifica com reto raciocínio, relacionado à poiésis.

Entre as coisas variáveis estão incluídas as coisas feitas e as ações praticadas, pois fazer e agir são coisas diferentes [...]; Tampouco uma delas é parte da outra, pois nem agir é fazer, nem fazer é agir [...] e não há arte alguma que não seja uma disposição relacionada com fazer, nem há qualquer disposição relacionada com fazer que não seja uma arte, $a$ arte é idêntica $a$ uma disposição da capacidade de fazer,

1 O poeta faz poemas que constituem sua poesia. Relação específica das artes miméticas. Verificar o texto Poética, de Aristóteles.

2 No afamado livro VI da Ética a Nicômaco, ao descrever as virtudes dianoéticas (ou excelências intelectuais), Aristóteles afirma que "as disposições em virtude das quais a alma possui a verdade, quer afirmando, quer negando, são em número de cinco: a arte, o conhecimento científico, a sabedoria prática, a sabedoria filosófica e a razão intuitiva" (Étic. Nic., VI 3, 1139b 20 - itálicos nossos). Isto é, Aristóteles, afirma, ao menos, que tais virtudes "possuem (ou alcançam) a verdade" de algum modo, e, portanto, parece-nos admitir que tais virtudes ou excelências intelectuais podem ser caracterizadas ou consideradas também como formas de "saber" (ou ao menos de proceder ou argumentar), o que chamaremos de formas de racionalidade. 

(Étic. Nic. VI 4 - 1139b35-1140a - itálicos nossos).

A expressão héxis metá logou alethoús poietiké poderia ser traduzida como "hábito produtivo acompanhado de (um) lógos verdadeiro". Portanto, esta disposição racional (ou hábito), proveniente de uma potência (dýnamis) específica da alma (psyché), própria da arte, é essencialmente definida através de um lógos específico, que de certo modo - enquanto processo ou modo de proceder - se identifica com o méthodos específico com que cada forma de arte expressa sua racionalidade. Além disso, este lógos, isto é, esta forma de racionalidade específica da arte, "possui verdade"*, e por isso, de tal modo, também a arte é compreendida como forma de saber específica (a arte retórica, ou a arte poética, por exemplo), inserida no gênero das ciências produtivas (epistême poietikê).

Tal lógos versa, de algum modo, acerca do universal, e por isso, a arte se assemelha (embora se mantenha distinta), da ciência (epistême); pois, "O conhecimento científico é um juízo sobre coisas universais e necessárias [...] o que pode ser cientificamente conhecido é passível de demonstração, enquanto a arte [poiésis] e a sabedoria prática [phrônesis] versam sobre coisas variáveis" (Etic. Nic. VI 6 - 1140b 35). Sendo assim, é evidente que o ato produtivo (poiésis) próprio da arte (techné) se distingue da ciência (epistême), especialmente porque a ciência versa sobre seres necessários, enquanto a arte o faz acerca dos seres imersos na contingência; embora ambas se ocupem de tais classes de seres (distintas entre si), através de uma espécie de raciocínio, um lógos verdadeiro, peculiarmente 
relacionado com o universal, que se identifica com a racionalidade inerente ao ato de produção, que se exprime através do méthodos peculiar a esta forma de proceder específica, e que portanto é passível de se constituir como espécie de conhecimento científico alcançado através de análise formal dos elementos constituintes destas formas de discursividade (lógoi) "produtivas" porque cumprem a "função" ou o "efeito" (érgon) através das palavras, específico: por exemplo, a persuasão (peithós) buscada pelos discursos retóricos, ou a "expurgação" (kathársis) dos excessos dos sentimentos de terror (phóbos) e piedade () acarretada pelos poemas trágicos.

Aristóteles circunscreve a arte no âmbito da classe do variável, definindo-a como uma capacidade raciocinada de fazer, ou de criar, que envolve um método, ou modo de raciocinar, verdadeiro. Por isso, o filósofo descreve que tal capacidade acompanhado de um lógos falso é a carência ou falta de arte.

a arte [...] é uma disposição relacionada com a criação, envolvendo um modo verdadeiro de raciocinar, e a falta de arte, que é o contrário da arte, é também uma disposição relacionada com a criação, mas envolvendo um método falso de raciocinar. E ambas se relacionam com as coisas variáveis (Etic. Nic. VI, 4 - 1140a 10 - itálicos nossos).

Sendo assim, mais do que hábito ou disposição de criar, inventar, ou fazer, a arte, em Aristóteles, é caracterizada como tal disposição, porém, acompanhada do método verdadeiro, ou o raciocínio correto, ou seja, o lógos verdadeiro.

Respectivamente, a arte (teckné); a ciência ou 
conhecimento científico (epistême); a sapiência ou sabedoria filosófica (sophía); a prudência, ou discernimento, ou sabedoria prática (phrônesis); e a razão intuitiva ou inteligência (nôus), são as espécies de excelências dianoiéticas, ou "virtudes" intelectivas, às quais o ser humano pode discorrer, proceder ou argumentar, tendo em vista diferentes fins, a partir de "caminhos" (méthodoi) diversos, e modos singulares de raciocínio específico, através, possivelmente, de um método próprio, e - especialmente - de se relacionar ou alcançar a verdade (alethéia) de algum modo. A tais excelências (aretái), do pensar humano (dianóia), nos interessa admiti-las como formas de racionalidadeou de discursividade; bem como, como formas de saber (epistême), já que - como dito anteriormente -, tais virtudes "possuem verdade".

Também na Metafísica, de forma distinta, Aristóteles procede à elaboração de uma teoria do conhecimento, na famosa exposição do livro I, capítulo 1, da Metafísica ${ }^{3}$. Inicialmente, assim, desde as sensações (aisthésis) compartilhadas por todos os animais -, até a sapiência (isto é, a sophía), como "uma ciência (epistême) acerca de certos princípios (archái) e certas causas (aitíai)" (Met. I 1, 982a), Aristóteles define a techné, ou seja, a arte, como "um juízo geral e único passível de ser referido a todos os casos semelhantes" (Metafísica, I 1 - 981a 5). No entanto, acreditamos que devemos ser cautelosos em afirmar que a arte, neste sentido, visa a um universal de maneira semelhante ao da ciência, pois a expressão "juízo geral" se assemelha com aquilo que poderíamos entender como

3 Alcunhada, por alguns, como a "gênese do universal"; já que se trata de uma espécie de ascensão ou ao menos de "elevação". Porém, devemos ressaltar que em tal teoria do conhecimento não há um desligamento efetivo com as etapas ou degraus anteriores, mas sim uma espécie de "superação", através do agrupamento de sensações (ou de experiências), cujos objetos possuem atributos em comum.

94 • Ágora Filosófica, Recife, v. 21, n. 2, p. 88-114, mai./ago., 2021 
"concepção universal", como parece ser de se esperar no caso da ciência; pois, "Os empíricos conhecem o puro dado de fato, mas não seu porquê; ao contrário, os outros [isto é, os artistas e cientistas], conhecem o porquê e a causa" (Met. I 1, 981a 30).

Por isso, a esta altura, vale-nos à pena mencionar que, para Aristóteles, a expressão "a arte é conhecimento dos universais" (Met. I 1981 a 15), deve ser entendida como a noção que, também a arte, conhece, de algum modo, as causas (isto é, os porquês), das coisas; porém, não do mesmo modo, e não das "mesmas coisas" com que a ciência e a sapiência as conhecem. ${ }^{4}$ Pois, a arte efetivamente conhece as causas dos seres compreendidos na sensibilidade, e portanto, contingentes, mais especificamente os seres produzidos pelos seres humanos; pois, "todas as ações e as produções referem-se ao particular" (Met. I 1 981a 15-20). Isto é, a arte se refere ao que Aristóteles apontará - na Ética a Nicômaco - como os entes que compõem a "classe do variável", pois a experiência (empeiría), conhece o particular como uma espécie de "agrupamento" das diversas sensações semelhantes, ou da mesma espécie, que se referem, entretanto, aos fatos particulares, já que as sensações apontam para "puro dado do fato", já que "as sensações são, por excelência, os instrumentos de conhecimento dos particulares, entretanto não nos dizem o porquê de nada: não dizem, por exemplo, por que o fogo é quente, apenas assinalam o fato de ele ser quente" (Met. I 1, 981b 10).

4 Para aprofundar possíveis distinções entre o lógos distintivo da arte, e o da phrônesis (e o da epistême), verificar: PENNA, Tiago. A racionalidade da arte poética em Aristóteles. Disponível em: 


\subsection{Racionalidade e Método em Aristóteles}

A partir da presente excursão, devemos averiguar se, a cada um destes âmbitos do discurso, existem procedimentos racionais próprios constitutivos, e se tais procedimentos se identificam com o método próprio de cada espécie de argumentar ou de proceder, e, ainda, se podem ser admitidos como formas de racionalidade, e se isso implica que possamos admitir que tais formas de racionalidade possam ser concebidas - de algum modo como formas de saber.

Neste sentido, nos debruçaremos sobre o âmbito da racionalidade e do método de forma geral, e investigaremos se também a arte, em geral, e a retórica, em particular, podem ser concebidas como formas de racionalidade, e se podemos identificar a racionalidade retórica com seu método específico, enquanto modo de proceder ou de criar argumentos ou de discursar, e se isso implica de algum modo em admitir que a arte, em geral, e a retórica, em particular, pode ser concebida como formas de saber, em Aristóteles.

Se intentarmos em admitir que a arte, em geral, e a retórica, em particular, incidem em uma forma de racionalidade específica, e se nos parece que, de algum modo, elas podem se apresentar como formas de saber específicas, resta-nos analisar como podemos conceber 0 termo racionalidade, e se, desta feita, a mesma se assemelha com o método próprio de cada forma de saber. Para Berti (2002, p. VIII), a racionalidade não é concebida inicialmente como a faculdade do raciocínio, porém como os discursos ou argumentos constituídos pela mesma. Sendo assim, deveríamos admitir que, estabelecida as diferentes formas de discursividade em Aristóteles, teríamos diferentes formas de argumentar, e assim, de 
defendermos ou refutarmos uma tese, de modo que cada uma delas parece se identificar com uma forma de saber específica (isto é, tomada singularmente), ou seja, tais formas de racionalidade, de algum modo, têm como escopo o "relacionar-se com a verdade"; e se - ao menos suas racionalidades específicas são idênticas aos métodos próprios de cada uma destas formas de racionalidade ou de saber (epistême) - assim concebidas exatamente por admitirem algum tipo de "relação" com a verdade (alethéia).

\section{Retórica enquanto Techné}

Falaremos do âmbito da retórica, que em Aristóteles tem um ponto que, embora dúbio, é certo: a retórica é uma arte que se relaciona com o contexto da ética e da política. Portanto, a distinção didática generalizada de que a retórica (como a poética), é uma espécie de "prática" que se relaciona, ou que serve como uma espécie de "instrumento" ou propedêutica para as ciências práticas (epistemái praktikê), embora verdadeira, não nos parece suficiente para que reconheçamos a essência da retórica como ciência "produtiva" (epistême poietikê) ou ciência poiética. Pois, se é assente que a arte relaciona-se com a classe do variável, e, portanto, seus produtos ou artefatos e-laborados estão inseridos no âmbito das coisas contingentes (o que se torna óbvio pelo fato de possuírem matéria), gostaríamos de ressaltar que, no entanto, se intentamos em conceber também arte, e, especificamente, a retórica, como uma forma de racionalidade específica, nos é lícito concordar com Aristóteles, quando o mesmo afirma que:

Toda arte visa à geração e se ocupa em inventar e em considerar as maneiras de

Ágora Filosófica, Recife, v. 21, n. 2, p. 88-114, mai./ago., 2021 • 97 
produzir alguma coisa que tanto pode ser como não ser, e cuja origem está no que produz, e não no que é produzido [...] logo, como já dissemos, a arte é uma disposição que se ocupa em produzir, envolvendo o reto raciocínio (Étic. Nic. VI 4, 1140a 10 - itálicos nossos).

Sendo assim, há um lógos subjacente à arte. Exatamente com respeito a este lógos distintivo e constitutivo da arte podemos identificar com a racionalidade da arte (embora acreditemos que, não apenas com respeito a tal raciocínio peculiar da atividade criadora ou inventiva da capacidade ou disposição em produzir algo diferente de si mesmo, do agente inteligente que o produz), que diz respeito ao método (méthodos), ou a um "modo verdadeiro de raciocinar", ou ainda à arte tomada como forma de saber poiético (epistême poietikê).

Logicamente, de acordo com a teoria do conhecimento aristotélica (especialmente descrita na Metafísica), a arte (teckné), ocupa um lugar intermediário entre a experiência (empeiría) prática, e a ciência (epistême), sendo esta entendida como faculdade plena do conhecimento científico, em Aristóteles. Pois, ao estabelecer um paralelo entre a retórica e a dialética, enquanto maneiras de "questionar e sustentar um argumento, defender-se ou acusar" (Ret. I 1, 1354a 5), Aristóteles irá dizer:

Simplesmente, na sua maioria, umas pessoas fazem-no ao acaso, e, outras, mediante a prática que resulta do hábito. $\mathrm{E}$, porque os dois modos são possíveis, é óbvio que seria também possível fazer a mesma coisa seguindo um método [...] e todos facilmente concordarão que tal estudo é tarefa de uma 
arte [teckné] (Ret. I 1, 1354a 10 - itálicos nossos).

Parece-nos curioso que Aristóteles admita que é possível também versar, na arte retórica, e até mesmo na dialética, "por acaso" ${ }^{5}$, ou, o que parece mais evidente, por uma "prática que resulta do hábito", pois já na Ética a Nicômaco, Aristóteles reitera que o hábito é adquirido por repetição das ações (ou, no caso específico das excelências morais, também das emoções); pois, "nem por natureza nem contrariamente à natureza a excelência moral é engendrada em nós, mas a natureza nos dá a capacidade de recebê-la, e esta capacidade se aperfeiçoa com o hábito" (Etic. Nic. II 1, 1103a 30).

No entanto, a nós importa observar que o filósofo argumenta que é possível alcançar a $\operatorname{arte}^{6}$ através de um método (méthodos), no qual o lógos distintivo da arte seja alcançado ou concebido, de modo que seja tomada posse da verdade poiética, e, portanto, estritamente ligada à habilidade (techné) na produção (poiésis) e na "efetividade" (érgon) de sua finalidade última (télos), que se identifica com a persuasão (peithós), no caso da arte retórica. Portanto, de acordo com tal maneira de raciocinar ou conceber o raciocínio, intentamos em defender que, a racionalidade específica da arte também poderia ser entendida como uma forma de "saber prático", isto é, que pode ser adquirido sem o conhecimento formal de suas "regras" de com-posição de discursos (lógoi), ou pode ser "apropriado" intuitivamente.

5 Além da célebre referência, na Ética a Nicômaco, ao poeta Agatão, de que "A arte ama o acaso, e o acaso ama a arte" (VI 4, 1140a 10).

6 A arte (techné) é uma espécie de saber teórico (epistême) que resvala na prática (praktikê), ou, para sermos mais precisos, que se estabelece como inserida no gênero das ciências produtivas (epistême poietikê).

Ágora Filosófica, Recife, v. 21, n. 2, p. 88-114, mai./ago., 2021 • 99 
3.1 Retórica e Dialética

A opinião mais difundida é que o método dialético ${ }^{7}$ (que inclusive Aristóteles se serve em algumas passagens da Metafísica ${ }^{8}$ ) é - em oposição ao método analítico como que o lugar (tópos) dos demais gêneros de saber (que não, portanto, o da razão apodítica - necessária e universal - própria da epistême). Porém, Aristóteles afirma, de início, "A retórica é a outra face da dialética; pois ambas se ocupam de questões mais ou menos ligadas ao conhecimento comum e não correspondem a nenhuma ciência em particular" (Retórica, I 1 - 1354a - itálicos nossos). Em nossa opinião, a análise desta assertiva, que aparentemente é simples, pode nos ajudar a compreender a topologia e o lugar da retórica no pensamento aristotélico.

O termo "retórica" (rethoriké) corresponde à noção abstrata do nome tomado como adjetivo, que corresponde a ideia subjacente de "arte" (techné); isto é, à concepção que, de fato, a retórica é uma arte tomada de modo abstrato, ou seja, entendida como o ato de fazer ou produzir (poiésis) algo (daí sua classificação didática como "ciência poiética"). Além de que, "a outra face" se refere ao termo anthístrophos ("antístrofe"), que corresponde ao movimento contrário da estrofe na lírica coral; de modo que ambas, a retórica e a dialética, coordenam-se de forma complementar porém oposta, isto é, são artes, técnicas, ou métodos que têm semelhanças e diferenças

\footnotetext{
7 O que chamamos de método dialético é o méthodos da ciência (epistême); que, em Aristóteles, é fundamentado pelo Silogismo, que a partir de premissas tomadas como necessárias (e verdadeiras), conclui, de modo necessário, uma nova assertiva, cujo atributo essencial é o da necessidade e universalidade, próprias da razão apodítica, que sustenta ontoepistemologicamente, a ciência (epistême).

8 Cf., por exemplo, I 2 - 982a 5 em diante, no levantamento (elenkós) das opiniões (endóxai) acerca do sábio e da sapiência.

100 • Ágora Filosófica, Recife, v. 21, n. 2, p. 88-114, mai./ago., 2021
} 
gerais e específicas entre si. Assim, nos parece que seus modos de proceder têm similitudes que as tornam irmanadas, pois a partir do conhecimento e da prática de ambas é possível percorrer diferentes caminhos, ou até mesmo opostos, e portanto diaporéticos ${ }^{9}$.

Porém, defendemos que a racionalidade peculiar à retórica contém elementos que a distingue da dialética, a partir de suas correspondentes topologias, se tomadas de modo específico. Pois, nas palavras de Aristóteles, essas duas formas de proceder se relacionam com os saberes comumente aceitos, ou seja, as opiniões comuns (endóxai), e, assim, são "funcionam" como propedêutica do gênero das ciências práticas (epistême praktikê), ou seja, a ética e a política. Por isso, também na Ética a Nicômaco, bem como na Retórica, Aristóteles faz considerações metodológicas, e disserta, nesta última, acerca da natureza da retórica. De fato, tanto a dialética quanto a retórica apoiam-se em opiniões comuns, ou comumente aceitas, através de um método (méthodos) específico, que para nós se identifica com aquilo que chamamos de racionalidade.

Porém, o estagirita admite três utilidades para o conhecimento prático da dialética: para o exercício, para os encontros casuais, e para as ciências filosóficas ${ }^{10}$. Porém, do mesmo modo quanto ao interesse da aquisição da arte retórica através de um método, nos interessa, na presente investigação, a utilidade da dialética para as ciências filosóficas.

9 Verificar em Aristotle el les problêmes de méthode, comunicação apresentada no Symposium Aristotelicum, que a diaporia remete à segunda etapa do percurso filosófico, ou do filosofar, em Aristóteles, após a etapa de aporia, até então atingir a euporía.

10 Verificar análise do papel da dialética em Aristóteles, a partir do tópico 2 do capítulo VI do livro Ciência e Dialética em Aristóteles, de Oswaldo Porchat Pereira, publicado pela editora Unesp.

Ágora Filosófica, Recife, v. 21, n. 2, p. 88-114, mai./ago., $2021 \cdot 101$ 
Pois, expondo-a, Aristóteles descreve-nos a dialética como uma propedêutica às ciências 'filosóficas' em geral [...]; como um método que conduz, mediante um raciocínio diaporemático, à apreensão dos princípios científicos. E o filósofo invoca explicitamente a anterioridade absoluta dos princípios [...] para argumentar em favor da necessidade de discorrer sobre eles a partir das endóxa [sic.], isto é, de proposições aceitas pela opinião, que a dialética converte em premissas de seus raciocínios (PORCHAT, 2001, p. 357 itálicos no original).

A partir disto assente, percebemos que a dialética é uma espécie de propedêutica ou iniciação às demais ciências filosóficas. E se já concordamos com Aristóteles que a retórica é a "outra face" (antístrofe), da dialética, é óbvio que também a retórica irá apoiar-se sobre as endóxas. Mesmo que não adentremos na problemática histórica de cunhar os cinco livros sobre lógica com o termo Organon ("instrumento"), devemos ressaltar que, para Aristóteles, tanto a dialética quanto a retórica são neutras axiologicamente, isto é, não são essencialmente boas nem más, pois tal qualificação seria originária do bom ou mau uso que as pessoas fazem destas artes, ou técnicas de discursos (ou modos de proceder), pois ciente do uso instrumentalizado histórica e hegemonicamente arraigado da retórica desde o seu tempo, Aristóteles irá alertar-nos, em uma espécie de autocrítica:

$E$, se alguém argumentar que o uso injusto desta faculdade da palavra pode causar graves danos, convém lembrar que o mesmo argumento se aplica a todos os bens exceto à virtude [...], pois, sendo usados justamente, poderão ser muito úteis, e, sendo usados 
injustamente, poderão causar grande dano (Ret. I 1, 1355b 5).

Além disso, é uma característica, tanto da dialética quanto da retórica, que por recorrer às opiniões comuns, podem ser consideradas universalizáveis, isto é, têm a capacidade de discorrer ou versar sobre "todos" os assuntos de maneira geral; contanto que não nos esqueçamos de que a retórica o faz no âmbito da dóxa (opinião), que para Aristóteles tem seu lugar de prestígio e importância, embora de modo algum exclua o conhecimento efetivamente científico, e por isso rigoroso, da epistême.

\subsection{As Especificidades da Arte Retórica}

Ao definir a retórica, Aristóteles irá também expor tais características como essenciais desta arte.

Entendamos por retórica a capacidade de descobrir o que é adequado a cada caso com o fim de persuadir. Esta não é seguramente a função de nenhuma outra arte; pois cada uma das outras é apenas instrutiva e persuasiva nas áreas de sua competência [...]; o mesmo se passando com todas as outras artes e ciências. Mas a retórica parece ter, por assim dizer, a faculdade de descobrir os meios de persuasão sobre qualquer questão dada. $\mathrm{E}$ por isso afirmamos que, como arte, as suas regras não se aplicam a nenhum gênero específico de coisas (Ret. I 2, 1355b 30-35; itálicos nossos).

Um primeiro aspecto que poderíamos extrair em nossa interpretação deste trecho da Retórica, que define a retórica como uma capacidade ou disposição (dínamys), de 
"descobrir" o que em cada caso particular (isto é, concreto e inserido em um determinado contexto), com vistas à persuasão (pathêi), fim último desta forma de arte; é que, geralmente e de fato, conforme a Ética a Nicômaco, a arte é esta capacidade raciocinada de produzir, ou "fazer" (poíesis), algo, isto é, criar ou inventar algo para além do próprio agente inteligente que o produz.

No entanto, há algo que deve ser ressaltado, ao confrontarmos estas duas definições (de arte em geral, e da retórica, em particular), que é exatamente a conexão entre "criar" e "descobrir". De fato, esta é uma relação agraciada pelos gregos, a qual possivelmente se perdera entre nós - modernos - e que podemos buscar enfatizá-la recorrendo a uma passagem da Poética, que trata das formas de poesias, isto é, das "artes imitativas" (miméticas), com ênfase nas artes dramáticas. Aristóteles parece arguir que os poetas trágicos retiravam seus argumentos dos mitos tradicionais de homens "que gozam de grande reputação e fortuna, como Édipo e Tiestes ou outros insignes representantes de famílias ilustres" (Poet. XIII § 70, 1453a 10), que aponta para a origem das narrativas (mýthoi) poéticas a partir de mitos históricos tradicionais, além de que,

o poeta deve ser mais fabulador que versificador; porque ele é poeta pela imitação e porque imita ações. E ainda que lhe aconteça fazer uso de sucessos reais, nem por isso deixa de ser poeta, pois nada impede que algumas coisas que realmente acontecem sejam, por natureza, verossímeis e possiveis e, por isso mesmo, venha o poeta a ser o autor delas (Poet. IX \$54, 1451b 30 - grifos nossos).

Aristóteles, ao dizer que o poeta (isto é, o "fazedor" 
de poemas, ou seja, as obras de arte mimética), deve ser "mais fabulador que versificador", a partir da perspectiva exposta, parece-nos afirmar que mais do que versificar os mitos, isto é, dar-lhes uma forma bela, ou seja, constituída de "partes ordenadas, mas também uma grandeza que não seja qualquer" (Poet. VII §44, 1450b 35), deve "criar" os nexos de ação, para "representar o que poderia acontecer, quer dizer: o que é possível segundo a verossimilhança e a necessidade" (Poet. IX §50, 1451b - itálicos nossos). De modo que, em nossa compreensão, Aristóteles traz à tona uma relação estreita entre criação e descobrimento nas artes pelo poeta, pois ao "atribuir a um indivíduo de determinada natureza pensamentos e ações que, por liame de necessidade e verossimilhança, convêm a tal natureza" (Poet. IX \$50, 1451 b 10 - itálicos nossos), o poeta está de fato "desvelando" uma relação possível, e por isso plausível, da realidade no âmbito da ação humana, de forma que "criar" e "descobrir" fazem parte do mesmo processo de fabulação do poeta, cuja poesia participa da universalidade, pois, no caso das artes poéticas, especificamente as dramáticas, procede ao desvelamento "das verdadeiras relações que existem entre fatos; relações que, de algum modo, estão ocultas no próprio acontecer"11.

Ou seja, o poeta (no caso das artes miméticas), ou o retor (no caso da arte retórica), ao criar, desvenda ou descobre algo; qual seja, no caso do poeta, as relações entre ações por "necessidade e verossimilhança", ou seja, a conexão (causal) íntima entre as ações das personagens; ou, no caso do retor ou orador, a descoberta dos "meios de persuasão" sobre uma dada questão qualquer, que 
discorra sobre um caso concreto, e portanto particular, e que assim está inserido em um contexto, mas que não se refere a um gênero de ser específico, pois a retórica (assim como a dialética), é uma arte que remete a um modo de discursar específico, e por isso racional, mas que não se refere especificamente a um determinado gênero de ser.

\subsubsection{O possível, o Plausível e o Verossímil nas Artes Poiéticas}

Por outro lado, se a arte se debruça sobre a classe do variável, isto é, das coisas possuidoras de matéria, e que por isso mesmo são contingentes, embora a arte desvele relações formais entre as coisas imersas na sensibilidade, resta-nos compreender de que modo tais seres específicos se relacionam com tais tipos de relações formais; pois a arte possui uma relação determinada, ou melhor, refere-se de algum modo ao universal, de modo que o que é possível deve ocorrer "segundo", ou "de acordo com", a "verossimilhança e a necessidade", pois, "o que é possível é plausível; ora, enquanto as coisas não acontecem, não estamos dispostos a crer que elas sejam possíveis, mas é claro que são possíveis aquelas que aconteceram" (Poet. IX §52, 1451 b 17 - itálicos nossos).

Assim, no caso da retórica, se torna imprescindível distinguir o que seja o plausível e o verossímil, já que, de certo modo, no âmbito da dóxa não há uma verdade firme e inabalável, isto é, necessária (como seria de se supor no caso da ciência, epistême); porém, por outro lado, Aristóteles não exclui a possibilidade de distinguirmos o que seja verdadeiro, e plausível. Através do conhecimento propiciado pela arte retórica. 
Pois é próprio de uma mesma faculdade discernir o verdadeiro e o verossímil, já que os homens têm uma inclinação natural para a verdade [...] E, por isso, ser capaz de discernir sobre o plausível é ser igualmente capaz de discernir sobre a verdade [...] Mas a retórica é útil porque a verdade e a justiça são por natureza mais fortes do que seu contrário (Ret. I 1, 1355a 15-25 - itálicos nossos).

Portanto, a mesma faculdade humana distingue o verdadeiro do verossímil, e ser capaz de distinguir o plausível também é ser capaz de distinguir o verdadeiro. Assim, retornamos à relação entre retórica e dialética, pois também a esta última se faz crucial distinguir o verdadeiro silogismo, do paralogismo ou silogismo aparente, e para tanto, tal faculdade que distingue o plausível, o verossímil e a verdade, é exercitada por estas duas formas de discursividade.

É, pois, evidente que a retórica não pertence a nenhum gênero particular e definido, antes se assemelha à dialética. É também evidente que ela é útil e que a sua função não é persuadir mas discernir os meios de persuasão mais pertinentes a cada caso, tal como acontece em todas as outras artes [...] Além disso, é evidente que pertencem a esta mesma arte o credível e o que tem aparência de o ser, como são próprios da dialética o silogismo verdadeiro e o silogismo aparente; pois o que faz a sofística não é a capacidade mas a intenção (Ret. I 1, 1355b 10-15 - itálicos nossos).

A partir da neutralidade axiológica da retórica, e por sua semelhança com a dialética, Aristóteles ressalta que a retórica é útil porque, além de nos tornar capazes de 
argumentar (isto é, defender e acusar, sustentar ou refutar uma tese), acerca de assuntos díspares ou até mesmos contrários entre si, o retor não deveria, aos olhos de Aristóteles, "persuadir o que é imoral", nem deixar escapar "o real estado da questão"12 (Ret. I 1, 1355a 35), pois, o bom retor, irá saber e perceber que "a verdade e a justiça são mais fortes que seus contrários"13.

De fato, devemos ressaltar que Aristóteles parece apregoar que, apesar da neutralidade axiológica da retórica (bem como da dialética), a retórica é útil para se alcançar a verdade e a justiça (o que a aproxima da ética e da política, pois virtude e bem comum são as excelências de tais ciências práticas); no entanto, exatamente pelo fato de a retórica ser uma espécie de instrumento é que a real "intenção"14 do orador é que irá determinar se seu discurso será nobre ${ }^{15}$ ou danoso.

12 Daí a necessidade de discernir o verossímil do verdadeiro, mesmo no âmbito da dóxa. Lembrar que alethéia ("desesquecimento", desvelamento), significa simultaneamente, em termos filosóficos, Verdade e Realidade; o que pode dar ensejo a confusões ocasionadas pelo paralelo (natural entre os gregos), entre Metafísica e Epistemologia.

13 Nota-se a diferença peculiar, com relação à retórica, entre a utilidade desta arte apregoada por Aristóteles (que a aproxima por deveras da ética e da política), daquilo que histórica e hegemonicamente se tornou como uma espécie de apropriação pragmatista e utilitarista desta técnica, com vistas à dominação e subjugação milenar, conforme constatamos facilmente, se nos propusermos a perceber os malefícios e injustiças ocasionadas pelo "mau" uso da retórica desde a época de Aristóteles (vide acusação e condenação de Sócrates), até os dias atuais (vide dominação políticoeconômica através do convencimento ocasionado pela hegemonia cultural de países dominantes).

14 Também pela intenção, Aristóteles distingue o dialético do sofista, que produz, respectivamente, o silogismo dialético (verdadeiro), e o sofístico (aparente).

15 Lembremos que o termo kálos diz respeito ao "belo", que no âmbito da ação se traduz por "nobre". O belo, para o grego, também é o bom, o útil, e o agradável. Tais paralelos semânticos, predicativos, na realidade, são férteis para confusões e más interpretações, se levarmos em conta, por exemplo, a tradição judaico-cristã como balizadora de tais valores ou conceitos, ou se não compreendermos que o "útil" se distingue fortemente da apropriação utilitarista (pragmatista), que, nefastamente, até os dias atuais tem sido maioria.

108 • Ágora Filosófica, Recife, v. 21, n. 2, p. 88-114, mai./ago., 2021 


\subsection{Provas e Persuasão}

Sendo assim, aparentemente, o método de determinada arte se identifica com a racionalidade inerente ao saber poiético que caracteriza a arte, pois, no caso da retórica, por exemplo, o conjunto de princípios gerais e racionais que estudamos, e nos quais ensinamos a arte retórica, caracteriza o seu método próprio enquanto forma de saber específica (e, portanto, como uma "espécie de epistême").

Portanto, a arte, em geral, e a retórica, em particular, segundo Aristóteles, pode ser concebida como um conjunto de regras racionais que visa criar ou produzir uma espécie de discurso específico, que genericamente se relaciona a algo contingente, isto é, que poderia ser de um modo ou de outro, ou ainda, que poderia ser ou não ser. Tanto que o lógos que acompanha a disposição de fazer ou produzir algo - e que difere da disposição de agir (práxis) -, é crucial e distintivo, e, portanto, assumido como verdadeiro; de tal modo que o que distingue a arte, da ausência de arte, que também é definida como um hábito ou capacidade de produzir (porém destituída de raciocínio (lógos) verdadeiro, ou método correto), é justamente a "posse" ou concepção de tal lógos distintivo e específico da arte; de modo que o método ou raciocínio que acompanha a arte, neste caso, deverá ser verdadeiro ou correto.

A este percurso metodológico, que caracteriza a disposição criativa da arte, do ato da concepção (forma) presente previamente na mente do artista, à organização da matéria (potência) do produto ou objeto de arte (artefato), chamamos de racionalidade. E como, no caso da retórica, a matéria são as palavras organizadas segundo um fim em vista, é relevante mencionar que para 
se atingir a finalidade adequadamente, isto é, a persuasão - estritamente ligada a casos particulares, ou concretos -, é crucial a compreensão e a prática das "provas" (pístis), de persuasão (pathéi), de acordo com uma forma adequada, isto é, o lógos do discurso; o éthos (caráter) do retor (causa motora da retórica); e o páthos (paixões ou emoções suscitadas através das palavras), dos auditores. De tal modo que, o termo pístis, ordinariamente traduzido como fé ou meio de persuasão, em Aristóteles, neste caso específico, concordaremos em traduzi-lo como "prova", que, no entanto, podem ser classificadas como provas lógicas, éticas ou emocionais (patéticas), respectivamente. E ainda, Aristóteles irá distinguir as provas entre artísticas (ou técnicas), e não-artísticas (não-técnicas), dizendo que as primeiras se referem àquelas provas obtidas por meio das regras ou métodos próprios da arte retórica; enquanto as segundas dir-se-iam respeito àquelas obtidas "exteriormente", ou de modo alheio às regras de produção dos discursos retóricos.

Acreditamos, no entanto, que devemos concordar em assumir que pístis se refere ao estado de convicção obtido através de um raciocínio obtido por um discurso retórico; mas também, e mais crucialmente, ao méthodos inerente desta forma de arte que busca instaurar tal estado de confiança, através de premissas de argumentos dotadas de uma ou mais espécies de provas (éthos, páthos, e lógos). No entanto, na retórica, existem duas, e apenas duas formas de persuasão (peithós): o exemplo (que é uma forma de indução retórica), e o entimema (que é uma espécie de demonstração ou silogismo retórico); pois o retor parte de "opiniões reputáveis" (endóxai), isto é, comumente aceitas pelos auditores, de forma que, em suas demonstrações, se torna necessário omitir algumas 
premissas subentendidas pelo auditório, pois geralmente este é constituído por pessoas sem maiores instruções filosóficas, de modo que, se já são conhecidas, se torna difícil conduzir um discurso muito extenso de forma que os auditores o acompanhem,e por isso tal omissão se torna imprescindível. De todo modo,

\begin{abstract}
Demonstrar que algo é assim na base de muitos casos semelhantes é na dialética indução e na retórica exemplo; mas demonstrar que, de certas premissas, pode resultar uma proposição nova e diferente só porque elas são sempre ou quase sempre verdadeiras, a isso se chama em dialética silogismo e entimema na retórica (Ret. I 2, 1356b 15).
\end{abstract}

Assim, o exemplo ou paradigma corresponde à indução na dialética, quando se parte de casos particulares para outros casos gerais; enquanto o entimema corresponde ao silogismo demonstrativo da dialética, e o entimema é considerado, de fato, a verdadeira forma de persuasão da retórica, no sentido de que esta forma de persuasão utiliza-se do lógos do discurso, que, para Aristóteles, é o cerne das provas de persuasão através do discurso. Além disso, o fato de que Aristóteles ressaltar que as conclusões de tais formas de demonstração (entimemas) são resultantes de premissas que são válidas sempre ou quase sempre, isto é, no mais das vezes.

\title{
Conclusão: Topologia Retórica
}

O tópos, o lugar da retórica é o eikós, o campo do "provável", que se apoia, como dito, nas endóxas, ou 
opiniões geralmente aceitas pela maioria. Assim, no âmbito ético-político, toda argumentação é tópica, pois, diferentemente do silogismo demonstrativo próprio da ciência (epistême), no qual não há espaço para escolhas, no caso da argumentação típica tanto da dialética quanto da retórica, há decisão, pois a função legítima e essencial da retórica é a de preservar o diálogo através da homologia, isto é, da igualdade entre locutor e interlocutores (ou seja, entre o retor e os auditores), ou, em outras palavras, da capacidade de adaptação do retor para com o contexto dos auditores. Sendo assim, neste caso, a verdade é premissa do auditório.

A retórica, segundo Aristóteles, tem a pretensão de ser neutra axiologicamente, o que significa que esta forma de arte, em si, não é valorada moralmente. Por outro lado, o seu uso é determinado pela intenção do retor, que de certo modo é "determinada" pelo caráter e pelo pensamento do mesmo. Assim, o bom uso da retórica, que deverá fazer prevalecer a verdade e a justiça (já que para Aristóteles essas são "mais fortes" do que seus contrários), não é estritamente determinada pela essência da retórica, mas sim pelo éthos (caráter), do retor, que deve fazer desse elemento do discurso mais do que um mero jogo de palavras.

E mais, Aristóteles revela que também “Persuade-se pela disposição dos ouvintes, quando estes são levados a sentir emoção por meio do discurso, pois os juízos que emitimos variam conforme sentimos tristeza ou alegria, amor ou ódio" (Ret. I 2, 1356a 20 - itálicos nossos). Sendo assim, há todo um espaço para investigações de tais características essenciais da arte retórica e das demais formas de arte poiéticas; além de que se torna crucial distinguir a "utilidade" aristotélica, do pragmatismo 
instrumental através desta forma de arte; pois a verdadeira utilidade da retórica, segundo Aristóteles reside no discernimento da verdade e da justiça, mesmo que estritamente ligadas ao âmbito da dóxa, e portanto, como propedêutica da ética e da política.

\section{Referências}

ARISTÓTELES. Ética a Nicômaco. Trad. Leonel Vallandro e Gerd Bornheim. São Paulo: Nova Cultural, 1996. (Col. Os Pensadores.)

ARISTÓTELES. Ética a Nicômacos. Trad. Mário da Gama Kury. 4. Ed. Brasília: UnB, 2001.

ARISTÓTELES. Metafísica. Ensaio introdutório, texto grego com tradução e comentário de Giovanni Reale. 3 Tomos. Trad. Marcelo Perine. 2. ed. São Paulo: Loyola, 2005.

ARISTÓTELES. Poética. Tradução, comentários e índices analítico e onomástico de Eudoro de Souza. São Paulo: Nova Cultural, 1991. (Col. Os Pensadores.)

ARISTÓTELES. Poética. Texto bilíngue grego-português. Trad. Eudoro de Souza. São Paulo: Ars Poetica, 1993.

ARISTÓTELES. Retórica. Trad. Manuel Alexandre Júnior; Paulo Farmhouse Alberto, Abel do Nascimento Pena. São Paulo: WMF Martins Fontes, 2012.

BERTI, Enrico. As razões de Aristóteles. Trad. Dion Davi Macedo. 2. ed. São Paulo: Loyola, 2002.

HÖFFE, Otfried. Aristóteles. Trad. Roberto Hofmeister Pich. Porto Alegre: Artmed, 2008.

PEREIRA, Oswald Porchat. Ciência e dialética em Aristóteles. São Paulo: UNESP, 2001.

ROHDEN, Luiz. O poder da linguagem: a arte retórica de Aristóteles. Porto Alegre: EDIPUCRS, 1997. 
Tiago Penna

Professor Adjunto em Filosofia pela UFAL, desde 2008. Concluiu doutorado em Filosofia pela UFPB, em 2017, acerca da racionalidade poética em Aristóteles. Tem experiência em Filosofia Antiga, com ênfase em Aristóteles, e em Estética Contemporânea, com ênfase em Benjamin, Adorno, Deleuze e Flusser. Realizador audiovisual independente desde 1995. Endereço: UFAL/ Campus A. C. Simões; BR 104 s/n; Maceió - AL. E-mail: penna.tiago@gmail.com

Submetido: $22 / 08 / 2021$ Aprovado: 15/09/2021 